RESEARCH ARTICLE

\title{
No Correlation between Blood Benzene Levels and Luteinizing Hormone Plasma Values in Outdoor Workers
}

\author{
Francesco Tomei ${ }^{1}$, Maria Valeria Rosati ${ }^{2}$, Giovanna Lo Russo ${ }^{2}$, Lidia Ricci ${ }^{3}$, Felice Marco Damato ${ }^{3}$, \\ Tiziana Caciari ${ }^{1}$, Roberto Giubilati ${ }^{1}$, Teodorico Casale $^{1}$, Bendetta Pimpinella ${ }^{1}$, Stefania Marchione ${ }^{3}$, \\ Nadia Nardone ${ }^{1}$, Natale Mario di Luca ${ }^{3}$, Francesco Massoni ${ }^{3}$, Vincenza Anzelmo ${ }^{4}$, Roberto Massimi ${ }^{1}$, \\ Gianfranco Tomei ${ }^{5}$, Pasquale Ricci ${ }^{3}$, Carmina Sacco $^{3}$ and Serafino Ricci ${ }^{2,3, *}$
}

${ }^{1}$ Spin off Sipro, Via Stimigliano 5, 00199 Rome, Italy; ${ }^{2}$ Department of Anatomy, Histology, Medical-Legal and the Orthopedics, Specialty Scool of Occupational Medicine, Unit of Occupational Medicine, University of Rome "Sapienza", Viale Regina Elena 336, 00161 Rome, Italy; ${ }^{3}$ Department of Anatomy, Histology, Legal Medicine and Orthopaedics, Sapienza University of Rome, Rome, Italy; ${ }^{4}$ Institute of Public Health, Unit of Occupational Medicine, University of Rome "Cattolica del Sacro Cuore", Largo Agostino Gemelli, 8, 00168 Roma, Italy; ${ }^{5}$ Department of Psychiatric and Psychological Science, University of Rome “Sapienza ”, Piazzale Aldo Moro 5, 00185 Rome, Italy

\begin{abstract}
Purpose of the Study: The purpose of the study is to evaluate whether low-dose exposure to benzene, an environmental pollutant to which male and female traffic policemen are daily exposed to could cause alterations in plasma luteinizing hormone (LH) levels.

Materials and-Methods: From an initial sample of 1594 workers, we only selected 95 workers of whom study we knew the values of late-shift benzene and LH hormone. All subjects underwent biological monitoring (final blood benzene evaluation) and luteinizing hormone dosing. Excluding subjects with the main confounding factors, the final sample included 76 workers. The normal distribution of the variables was evaluated using the Kolmogorov - Smirnov test, followed by the logarithmic transformation of the $\mathrm{LH}$ and benzene values. The comparison among means was performed by using the $\mathrm{t}-$ test for the independent samples. The ANOVA test was performed for variables with more than 2 modes (ages and seniority) and Pearson correlation index between variables in the total sample and after subdivision as to sex, job, sports activity and smoking. The results were considered significant when $\mathrm{p}$ values were less than 0.05 .
\end{abstract}

Results / Conclusions: The study did not show a correlation between benzene levels and LH plasma levels in outdoor workers.

Keywords: Benzene, environmental pollutants, luteinizing hormone, outdoor workers, sexual hormones, traffic policemen.

\section{INTRODUCTION}

Benzene is an aromatic highly flammable compound with an intense smell, with high anti-knocking power, low viscosity, high solubility in polar solvents and low solubility in water. It is found in high quantities in oil or during combustion processes such as volcanic eruptions or blaze. It is used as an additive in fuels; in the industrial synthesis of organic compounds such as ethylbenzene (as a precursor of styrene, used to produce polymers, copolymers, plastic resins and latex), cumene (converted to phenol for the production of adhesives and resins), cyclohexane (used in the production of some types of nylon), nitrobenzene (for the production of aniline, paints and other products), alkylbenzene (for the production of detergents) and chlorobenzene (in the

*Address correspondence to this author at the Viale Regina Elena, 336 Zip Code: 00161 Rome, Italy; Tel: +390649912547; E-mail: serafino.ricci@uniroma1.it production of polymers, pesticides, varnish) [1]. The studies carried out by the Ramazzini Institute showed that it is a multi-potent carcinogen, capable of inducing many different types of cancer in several animal species, including oral cavity carcinoma, nasal cavities, skin, dermis, mammary glands, hepatic angiosarcoma, cancers of the lung and lymphomas and leukemia [2-6]. According to the International Agency for Research on Cancer (IARC), the effect of benzene on humans can cause acute myeloid leukemia and acute nonlymphocytic leukemia. [7, 8] Furthermore, benzene exposure was positively associated with acute lymphocytic leukemia, chronic lymphocytic leukemia, multiple myeloma, nonHodgkin's lymphoma. Inhalation of benzene at low levels, but for a long time, is the main concern for the general population. This is because benzene is mainly inhaled through contaminated air in the general population [9-11]. Many professions, such as traffic policemen, are highly exposed to environmental stress factors (atmospheric pollutants) and 
psychosocial stress factors [12]. Data from studies on animal suggest that chemical "agents" such as toluene $[13,14]$, lead [15-17], cadmium [18, 19], styrene [20], could cause alterations on the synthesis, secretion and / or action of some hormones [21], including luteinizing hormone (LH) [22, 23]. The aim of the study is to verify whether a correlation between levels of blood benzene and of the luteinizing hormone can be found in a group of outdoor workers of a large city in Italy (Rome).

\section{MATERIALS AND METHODS}

\subsection{Studied Population}

The study was conducted on an initial sample of 1594 outdoor policemen, men and women, assigned to different outdoor duties divided as follows: traffic policemen, drivers/second patrol, motorcyclists, policemen of the core assistance to marginalized and other outdoor activities. All workers underwent a questionnaire for information on their physiological, pathological, occupational, pharmacological history, and history of their reproductive health (menarche, pregnancy, type and number of deliveries, menopause, date of the last menstrual cycle, current disorders of menstrual cycles by length and quantity, gynecological or endocrinological diseases in progress), and other information including mental health disorders collected according to a binary method (yes / no). In addition, data on the biological monitoring of benzene and data on laboratory tests were collected. As to exposure to cigarette smoking, we took into account the classification of the World Health Organization (WHO, 2014), considering all the smokers as the subject who declared in their history that they had smoked at least 100 cigarettes during their life, whether they were stile smokers or they had stopped smoking less than six months before [24, $25]$. As to the criteria of distinction between subjects practicing or not, we took into account the classification of the World Health Organization (WHO, 2010), considering at least 150 minutes per week of moderate activity or 75 minutes of vigorous activity (or equivalent combinations of the two) in sessions of at least 10 minutes at a time, with strengthening of the major muscle groups performed at least twice a week [26]. All workers who claimed they had stopped smoking more than 6 months before were considered non-smokers (WHO, 2014). Considering that an Alcoholic unit (typically 12 grams of ethanol) corresponds to an average glass of wine (about $150 \mathrm{ml})$, or a can of beer (333 $\mathrm{ml}$ ), or a small glass of spirits (about $40 \mathrm{ml}$ ) [27], consumers of more than 2 Alcohol Units per day for men and 1 Alcoholic Unit for women were considered regular drinkers of alcohol. We selected only workers with a known level of benzene at the end of the shift and LH hormone (95). To avoid the influence of confounding factors, we excluded workers exposed to solvents, paints and pesticides [28, 29] (n ${ }^{\circ} 3$ ), or women in menopause, (considering 51.4 years the average age of last menstruation) [30] (n²), workers following hormone replacement therapy [31] $\left(\mathrm{n}^{\circ} 1\right)$, pregnant women $\left(\mathrm{n}^{\circ} 1\right)$, or breastfeeding $\left(\mathrm{n}^{\circ} 1\right)$, women taking oral contraceptives [32] $\left(n^{\circ} 5\right)$, or having gynecological pathologies $\left(\mathrm{n}^{\circ} 2\right)$, infertility problems $\left(\mathrm{n}^{\circ} 1\right)$ or endocrinological pathologies, such as thyroid diseases $\left(n^{\circ} 1\right)$, polycystic ovary [33] $(n \circ 1)$.
Each subject consented to the processing of their personal data, declaring they knew that these data fell into the category of sensitive data and agreed that the data generated by the protocol were treated anonymously and collectively, in scientific ways and purposes in accordance with the principles of the Declaration of Helsinki. Each subject was informed about the purpose and method of the study and gave written consent to take part in the study itself.

\subsection{Statistical Analysis}

For statistical evaluation, we considered: age, job assignment, gender, seniority, smoking habits, alcohol/spirits intake and sports activities. The final sample was at the end composed of 76 workers (66 men and 10 women, 22 smokers and 54 non-smokers, 21 alcohol / super alcoholic drinkers and 55 non-drinkers, 26 sportsmen and 50 nonsportsmen). As to the task they carried out, they were n. 51 road workers and n. 25 workers with other outdoor tasks. All of them underwent biological monitoring (assessment of end-shift blood benzene) and the luteinizing hormone dosage (Table 1).

\subsection{Environmental Monitoring: Individual Dosimetry}

We performed n. 8 dosimetries on road workers selected from 8 different sites considered representative of the topographic distribution of the workers studied, as well as n. 4 dosimetries for drivers in service cars in which there were at least $\mathrm{n}$. 2 agents for each work shift. In any case, even if only one worker was wearing the dosimeter, the results obtained were considered representative of the exposure of his/her colleague of shift.

Blood samples and air samples had parallel processing for all the participants to avoid the influence of weather and seasonal conditions. Workers were equipped with individual passive diffusion dosimeters, attached as a badge to the worker's neck at the beginning of each sampling day in order to measure the concentration of benzene in the breathing area.

After sampling, the passive samplers were prepared for desorption by adding carbon disulphide to the badges. The benzene analyses were performed by capillary gas chromatography (GC) with Dani gas chromatograph 1000 equipped with a flame ionization detector (FID) for quantification. The limit of detection for benzene (LoD) was $0.001 \mathrm{ppm}(3.19 \mu \mathrm{g}$ / $\mathrm{m} 3$ ). The concentrations of benzene we found were expressed as average values over a period of 8 hours.

\subsection{Dosage of LH and Benzene}

Individual blood samplings for the determination of the LH and blood benzene parameters were performed after 5 continuous working days at the end of the work shift, on the same day of the benzene in the air. After distribution of an information note containing the recommendation to abstain from active and passive smoking on the five days prior to the examination, to avoid the consumption of certain foods (offal, chicken, fish and nuts) and the intake of alcoholic or super alcoholic beverages [33], during work shift and / or night shifts. A venous blood sample of $10 \mathrm{ml}$ was taken from 
Table 1. Characteristics of the studied population divided by task.

\begin{tabular}{|c|c|}
\hline Number of Subjects & Campione Totale \\
\hline Number of subjects & (n.76) \\
\hline Gender & \\
\hline Male ${ }^{\circ}(\%)$ & $66(86,8)$ \\
\hline Female $n^{\circ}(\%)$ & $10(13,1)$ \\
\hline Working (ys) road & \\
\hline Traffic policemen $n^{\circ}(\%)$ & $51(67,1)$ \\
\hline Policemen with other outdoor activities $n^{\circ}(\%)$ & $25(32,8)$ \\
\hline \multicolumn{2}{|l|}{ Smoking habits } \\
\hline Yes n ${ }^{\circ}(\%)$ & $22(28,9)$ \\
\hline NO n ${ }^{\circ}(\%)$ & $54(71,0)$ \\
\hline \multicolumn{2}{|l|}{ Alcohol } \\
\hline Yes n ${ }^{\circ}(\%)$ & $21(27,6)$ \\
\hline NO n ${ }^{\circ}(\%)$ & $55(72,3)$ \\
\hline \multicolumn{2}{|l|}{ Sport } \\
\hline Yes n ${ }^{\circ}(\%)$ & $26(34,2)$ \\
\hline $\mathrm{NO} \mathrm{n}^{\circ}(\%)$ & $50(65,7)$ \\
\hline \multicolumn{2}{|l|}{ Age (ys) } \\
\hline Median (SD) & $56(9,28)$ \\
\hline Geometric Mean & 55,55 \\
\hline Min-Max & $38-74$ \\
\hline Median & 56 \\
\hline \multicolumn{2}{|l|}{ Working life (ys) } \\
\hline Median (SD) & $18(10,10)$ \\
\hline Geometric Mean & 15,44 \\
\hline Min-Max & $6-37$ \\
\hline Median & 17 \\
\hline \multicolumn{2}{|l|}{ Benzene } \\
\hline Median (SD) & $371,31(410,24)$ \\
\hline Geometric Mean & 220,82 \\
\hline Min-Max & $3,46-1926$ \\
\hline Median & 204 \\
\hline \multicolumn{2}{|l|}{ LH } \\
\hline Median (SD) & $3,46(3,45)$ \\
\hline Geometric Mean & 2,59 \\
\hline Min-Max & $0,25-19,6$ \\
\hline Median & 2,7 \\
\hline \multicolumn{2}{|l|}{ Air Benzene } \\
\hline Number of subjects Median (SD) & $817,28(10,42)$ \\
\hline Geometric Mean & 13,88 \\
\hline Min-Max & $5-36,6$ \\
\hline Median & 16,2 \\
\hline
\end{tabular}

$\mathrm{SD}=$ deviazione standardys $=$ anni each worker with EDTA. The samples were stored in a refrigerator at $+4{ }^{\circ}$ until the time they were transferred (in a special container and at the same temperature) to the laboratory where they were immediately centrifuged and then stored at $-20^{\circ} \mathrm{C}$ until the time they were analyzed (within 3 days). The laboratory performed the blood benzene dosage through extraction method with SPME technique (extraction with ethylacetate and esterification) and gas chromatography analysis with mass spectrometry detector (GC-MS) with detection limit $<150 \mathrm{ng} / \mathrm{L}$ (Hoet $\mathrm{P}$ et al., 2009). The limit of detection for luteinizing hormone (LoD) was $<0.5 \mathrm{mIU} / \mathrm{dl}$.

\subsection{Statistical Analysis}

For statistical evaluation, the following factors were considered: sex, cigarette smoking, consumption of alcohol/spirits, sports activity, task, age and seniority. The normal distribution of the variables was evaluated using the Kolmogorov-Smirnov test, which was statistically significant for end-of-turn Benzene and for the luteinizing hormone. This indicates a non-normal distribution of the parameters under study. For this reason, we converted the parameters into a logarithmic form.

The results of the biological monitoring (end-shift blood benzene) and of the Luteinizing hormone LH were expressed in terms of mean, standard deviation (SD), median and range (min-max). The concentrations lower than the LoD were replaced with the LoD divided by two. The comparison between the averages was made by the Student's T-test for independent variables in the case of two-mode variables: smokers/non-smokers, sportsmen / non-sportsmen, drinkers / non-drinkers, male/female, drivers / other outdoor tasks, and ANOVA for variables with more than 2 methods (age, seniority). In the end, the Pearson correlation index was calculated to verify the association level between the values of blood benzene and the values of LH in the total sample as well as after subdivision based on gender, task, habit, alcohol intake and sports activity. The results were considered significant when the $\mathrm{p}$ values were less than 0.05 . Statistical analysis was performed using the SPSS ${ }^{\circledR}$ Advanced Statistical TM software 21.0 (Table 2 ).

\section{RESULTS}

\subsection{LH, Blood Benzene and the Characteristics of the Studied Population}

The characteristics of the studied population, of the blood and atmospheric benzene are reported in Table $\mathbf{1}$. There are no statistically significant differences between the values of LH (variable test) in relation to benzene and the habit of cigarette smoking, alcohol, task, sport, sex.

\subsection{Environmental Monitoring of Benzene: Personal Do- simeters}

The level of individual exposure to atmospheric benzene is shown in Table 1. No sampling exceeded the limit value of 1.6 $\mathrm{mg} / \mathrm{m} 3$ of benzene proposed by the ACGIH for the professionally exposed subjects. The dosimeters also showed atmospheric values of benzene higher than $5 \mu \mathrm{g} / \mathrm{m} 3$ (in Italy, limit value for the protection of human health established by Ministerial Decree No. 60/2002, based on Directive 2000/69 / EC), for 6 out of 8 road workers and for 2 drivers out of 4 . 
Table 2. Pearson correlation coefficient (R) between $\mathrm{LH}$ and blood benzene, in the total sample and after splitting by gender, smoking, job type, alcohol and sporting habit.

\begin{tabular}{|c|c|c|}
\hline Variably & $\begin{array}{l}\text { Biological Indicator } \\
\quad(\text { Media } \pm \text { SD })\end{array}$ & LH \\
\hline Number of subjects & $371,31 \pm 410,24$ & $\begin{array}{l}\mathrm{r}:-, 037^{\mathrm{a}} \\
\mathrm{p}:, 749^{\mathrm{b}}\end{array}$ \\
\hline Male & $371,31 \pm 410,24$ & $\begin{array}{l}\mathrm{r}:-, 033^{\mathrm{a}} \\
\mathrm{p}:, 790^{\mathrm{b}}\end{array}$ \\
\hline Female & $377,38 \pm 418,53$ & $\begin{array}{l}\mathrm{r}:-, 193^{\mathrm{a}} \\
\mathrm{p}:, 593^{\mathrm{b}}\end{array}$ \\
\hline Smoking & $374,11 \pm 416,38$ & $\begin{array}{l}\mathrm{r}:-, 146^{\mathrm{a}} \\
\mathrm{p}:, 517^{\mathrm{b}}\end{array}$ \\
\hline No Smoking & $373,66 \pm 412,53$ & $\begin{array}{l}\text { r: }-, 060^{\mathrm{a}} \\
\mathrm{p}:, 669^{\mathrm{b}}\end{array}$ \\
\hline Alcohol & $377,15 \pm 412,41$ & $\begin{array}{l}\mathrm{r}:, 000^{\mathrm{a}} \\
\mathrm{p}:, 999^{\mathrm{b}}\end{array}$ \\
\hline No Alcohol & $376,00 \pm 414,89$ & $\begin{array}{l}\mathrm{r}:-, 041^{\mathrm{a}} \\
\mathrm{p}:, 764^{\mathrm{b}}\end{array}$ \\
\hline Sport & $371,31 \pm 410,24$ & $\begin{array}{l}\mathrm{r}:-, 131^{\mathrm{a}} \\
\mathrm{p}:, 524^{\mathrm{b}}\end{array}$ \\
\hline No Sport & $379,86 \pm 421,03$ & $\begin{array}{l}\mathrm{r}:-, 090^{\mathrm{a}} \\
\mathrm{p}:, 534^{\mathrm{b}}\end{array}$ \\
\hline Traffic policemen & $376,00 \pm 414,89$ & $\begin{array}{l}\mathrm{r}:-, 048^{\mathrm{a}} \\
\mathrm{p}:, 735^{\mathrm{b}}\end{array}$ \\
\hline $\begin{array}{l}\text { Policemen with other } \\
\text { outdoor activities }\end{array}$ & $368,50 \pm 412,31$ & $\begin{array}{l}\mathrm{r}:-, 019^{\mathrm{a}} \\
\mathrm{p}:, 930^{\mathrm{b}}\end{array}$ \\
\hline
\end{tabular}

$\mathrm{a}=$ The correlation was made after the transformation of blood benzene levels into logarithmic form

$\mathrm{b}=$ The correlation is statistically significant at p 0.01 level (two queues).

\subsection{LH and Blood Benzene}

Pearson's correlation analysis between blood benzene levels and LH values did not show any significant correlation, either in the total sample or in all the subgroups.

\section{DISCUSSION}

The California Environmental Protection Agency recognized Benzene as a toxic compound for the development and reproduction especially in male subjects $[34,35]$.

Urban pollutants could cause reproductive disorders in female [36] and male subjects [37-41]. Alterations of plasma LH levels are involved in mental health disorders as well as depression $[42,43]$ that influence the worker's efficiency and performance. The determination of the level of benzene [44] at the end of the shift, therefore, represents, to this day, the most sensitive and specific method as it reflects the exposure to benzene [45]. It is considered useful for the future to extend the case studies to other indicators present in the urine. $\mathrm{LH}$ is a glycoprotein hormone, in males it stimulates the testosterone production by the interstitial cells (Leyding cells) of the testis, in female subjects, the LH hormone together with another glycoprotein hormone FSH stimulates the production of estrogen, from the follicles, and progesterone, and it is responsible for the production of the ovarian androgenic quotas. In the middle of the menstrual cycle, a peak of LH causes the ovulation, with the formation of the corpus luteum whose activity is promoted and maintained by the LH [46].

A number of studies in the literature showed that exposure to chemical, physical [47] and psychosocial environmental pollutants [48, 49], can influence plasma LH levels [24, 25] policemen/women chronically exposed to urban stress [50]. Other studies showed the effects of some pollutants on the cardiovascular system [51-54], the respiratory system [55-56] and the Psycho-neuro-immunologic system [57, 58]. There is also evidence that benzene in the air affects both the hormonal structure [59, 60] and other organs and systems [61-63].

The individual dosimeters are representative of the different areas of the town and were carried out to quantify the exposure in the air. It should be noted that personal exposure to atmospheric benzene of police officers has always been within the limits of the ACGH for exposed workers, but often they were higher than the reference values of the general population. That is why we believe that the limits of the ACGH are too high for some working categories.

A study of the US aviation on female members of staff [64] highlights the effects of aliphatic and aromatic hydrocarbons for exposure to fuels such as JP8 (jet fuel) and diesel, a variety of solvents, including toluene and xylene, and combustion products of the fuel. The relationship between the exposure to the mentioned compounds and the reduced LH levels suggests that these compounds may act as reproductive endocrine disruptors.

In previous studies, LH levels in policemen [22] and in policewomen [25] were compared with a control group for exposure to urban pollutants. Carlo Monti et al. 2009 [24] showed a statistically significant increase in plasma LH levels in the policewomen. Enrico Tomao et al 2009 [25] showed that in the policemen, the levels of LH were significantly higher than in administrative staff.

In the current study, we have analyzed the benzene. It must be taken into account that in the following years, the concentrations of benzene in the air have decreased considerably following the new EU regulations.

\section{CONCLUSION}

According to our results, we believe that the effects of urban pollution detected in the previous studies mentioned may not be attributed to benzene, but to other pollutants.

It should be noted that we carried out a preliminary study. Our results showed no correlation between blood benzene levels and LH values in any of the groups studied, most 
likely in relation to the low levels of benzene exposure and the low number of samples; therefore, we believe further analysis should be performed on a larger series.

\section{ETHICS APPROVAL AND CONSENT TO PARTICIPATE}

Ethical approval was not required as it has been guaranteed anonymity to patients who underwent the medical examination. The sample, in fact, is not identifiable in the study.

\section{HUMAN AND ANIMAL RIGHTS}

No animals were used in this study. The research was performed in accordance with the ethical standards of the committee responsible for human experimentation (institutional and national), and with the Helsinki Declaration of 1975, as revised in 2013.

\section{CONSENT FOR PUBLICATION}

Written informed consent was obtained from all patients prior to the publication of the study.

\section{AVAILABILITY OF DATA AND MATERIALS}

Not applicable.

\section{FUNDING}

None.

\section{CONFLICT OF INTEREST}

The authors declare no conflict of interest, financial or otherwise.

\section{ACKNOWLEDGEMENTS}

Declared none.

\section{REFERENCE}

[1] Instituto Ramazzini: Cancerogeni / Benzene. http://www.ramazzini.org/cancerogeno/benzene/ (Accessed March 19, 2019)

[2] Maltoni, C.; Ciliberti, A.; Pinto, C.; Soffritti, M.; Belpoggi, F.; Menarini, L. Results of long-term experimental carcinogenicity studies of the effects of gasoline, correlated fuels, and major gasoline aromatics in rats. Ann. NY Acad. Sci., 1997, 837, 15-52

[3] Maltoni, C.; Conti, B.; Perino, G.; Di Maio, V. Further evidence of benzene carcinogenicity. Results on Wistar rats and Swiss mice treated by ingestion. Ann. N Y Acad. Sci., 1988, 534, 412-426

[4] Maltoni, C.; Cotti, G.; Valgimigli, L.; Mandrioli, A. Zymbal gland carcinomas in rats following exposure to benzene by inhalation. Am. J. Ind. Med., 1982, 3(1), 11-16

[5] Maltoni, C.; Ciliberti, A.; Cotti, G.; Conti, B.; Belpoggi, F. Benzene, an experimental multipotential carcinogen: results of the long-term bioassays performed at the Bologna Institute of Oncology. Environ Health Perspect., 1989, 82, 109-24.

4. Maltoni, C.; Cotti, B.; Cotti, G. Benzene: a multipotential carcinogen. Results of long-term bioassays performed at the Bologna Institute of oncology. Am. J. Ind. Med., 1983; 4(5), 589-630

[6] Arnold, SM.; Angerer, J.; Boogaard, PJ.; Hughes, MF.; O'Lone, RB.; Robison, SH.; Schnatter, AR. The use of biomonitoring data in exposure and human health risk assessment: benzene case study. Crit. Rev. Toxicol., 2013, 43(2), 119-53
IARC. Overall evaluations of carcinogenicity: an updating of IARC Monographs volumes 1 to 42. IARC Monogr Eval Carcinog Risks Hum Suppl. 1987, 7, 1-440

[8] ATSDR, Agency for Toxic Substances and Disease Registry. Toxicological profile for benzene. US Department of Health and Human Service, Public Health Service, Atlanta (GA), 2007.

Miraglia, N.; Genovese, G.; Basilicata, P.; Pieri, M.; Simonelli, A.; Guadagni, R.; Lamberti, M.; Pedata, P.; Acampora, A.; Sannolo, N. A case study of benzene urinary biomarkers quantification: the comparison between pre- and post shift samples improves the interpretation of individual biological monitoring data. Prev. Res., 2014, 3(4), 142-47

[10] Sancini, A.; Caciari, T.; Di Pastena, C.; Sinibaldi, F.; Scala, B.; Fiaschetti, M.; Nieto, HA.; De Sio S.; Maurizi, DC.; Nardone, N.; Scimitto, L.; Miracco, P.; Casale, T.; Giubilati, R.; Pimpinella, B.; Tomei, F.; Tomei, G.; Ciarrocca, M. Meta-analysis: cardiovascular effects in workers occupationally exposed to urban pollution. Prev. Res., 2011; 1, 87-100

[11] Collins, PA.; Gibbs, AC. Stress in police officers: A study of the origins, prevalence and severity of stress-related symptoms within a county police force. Occup. Med. (Lond)., 2003, 53(4), 256-64

[12] Luderer, U.; Morgan, MS.; Brodkin, CA.; Kalman, DA.; Faustman, EM. Reproductive endocrine effects of acute exposure to toluene in men and women. Occup. Environ. Med., 1999, 56(10), 657-66

[13] Svensson, BG.; Nise, G.; Erfurth, EM.; Nilsson, A.; Skerfving, S. Hormone status in occupational toluene exposure. Am. J. Ind. Med., 1992, 22, 99-107

[14] Pillai, A.; Priya, L.; Gupta, S. Effects of combined exposure to lead and cadmium on the hypothalamic-pituitary axis function in proestrous rats. Food Chem Toxicol., 2003, 41 (3), 379-84

[15] Priya, PN.; Pillai, A.; Gupta, S. Effect of simultaneous exposure to lead and cadmium on gonadotropin binding and steroidogenesis on granulosa cells: An in vitro study. Indian. J. Exp. Biol., 2004, 42 (2), 143-48

[16] El-Zohairy, EA.; Youssef, AF.; Abul-Nasr, SM.; Fahmy, IM.; Salem, D.; Kahil, AK.; Madkour, MK. Reproductive hazards of lead exposure among urban Egyptian men. Reprod. Toxicol., 1996, $10(2), 145-51$

[17] Lafuente, A.; Blanco, A.; Marquez, N.; Alvarez-Demanuel, E. Esquifino, AI. Effects of acute and subchronic cadmium administration on pituitary hormoes secretion in adult male rats. Rev. Esp. De. Fisiol., 1997, 53, 265-70

[18] Zeng, X.; Lin, T.; Zhou, Y.; Kong, Q. Alterations of serum hormone levels in male workers occupationally exposed to cadmium. J. Toxicol. Environ. Health. A., 2002, 65(7), 513-21.

[19] Jarry, H.; Gamer, A.; Wuttke, W. Effects of 5-day styrene inhalation on serum LH and testosterone levels and on hypothalamic and striatal amino acid neurotransmitter concentrations in male rats. Inhal. Toxicol., 2004; 16(4), 209-15

[20] Tomei, F.; Ciarrocca, M.; Cherubini, E.; Rosati, MV.; Monti, C. Capozzella, A.; Tomei, G. Prolactin levels in workers exposed to chemical, physical and psycho-social urban stressors. J Occup. Health., 2006, 48(4), 253-60

[21] Monti, C.; Ciarrocca, M.; Cardella, C.; Capozzella, A.; Rosati, MV.; Cherubini, E.; Fargnoli, S.; Casale, T.; Tomei, F.; Tomei, G. Exposure to Urban Stressor and Effects on Luteinizing Hormone (LH) in female outdoor workers. J. Environ. Sci. Health. A Tox. Hazard. Subst. Environ. Eng., 2006, 41(8), 1437-48.

[22] Tomao, E.; Tomei, G.; Rosati, MV.; Caciari, T.; Danese, D.; Gamberale, D.; Vacca, D.; Palermo, P.; Anzelmo, V.; Tomei, F. Luteinizing hormone (LH) levels in male workers exposed to urban stressors. Sci. Total. Environ., 2009, 407(16), 4591-5

[23] Sancini, A.; De Sio, S.; Gioffrè, PA.; Casale, T.; Giubilati, R. Pimpinella, B.; Scala, B.; Suppi, A.; Bonomi S.; Samperi I.; Rosati, MV.; Tomei, G.; Tomei, F.; Caciari, T. Correlation between urinary nickel and testosterone plasma values in workers occupationally exposed to urban stressors. Ann. Ig., 2014, 26 (3), 237-54

[24] Behavioral Risk Factor Surveillance System (BRFSS). Cigarette smoking among adults - New York State 2000. Tobacco use, cessation, and exposure to second-hand smoke among New York State adults.2003.

https://www.health.ny.gov/prevention/tobacco_control/reports/brfs s2001.htm (Accessed April, 2003)

http://www.euro.who.int/_data/assets/pdf_file/0006/147237/e9516 8.pdf 
[26] Saunders, JB.; Aasland, OG.; Babor, TF.; de la Fuente, JR.; Grant, M. Development of the Alcohol Use Disorders Identification Test (AUDIT): WHO Collaborative Project on Early Detection of Persons with Harmful Alcohol Consumption--II. Addiction., 1993, 88(6), 791-804.

[27] Luderer, U.; Bushley, A.; Stover, BD.; Bremner, WJ.; Faustman, EM.; Takaro, TK.; Checkoway, H,; Brodkin, CA. Effects of occupational solvent exposure on reproductive hormone concentrations and fecundability in men. Am. J. Ind. Med., 2004, 46(6), 614-26

[28] Kim, HS.; Shin, JH.; Moon, HJ.; Kang, IH.; Kim, TS.; Kim, IY.; Seok, JH.; Pyo, MY.; Han, SY. Comparative estrogenic effects of p-nonylphenol by 3-day uterotrophic assay and female pubertal onset assay. Reprod Toxicol. 2002, 16 (3), 259-68

[29] Faglia, G.; Beck-Peccoz, P.; Spada, A. Malattie del sistema endocrino e del metabolismo. $\mathrm{V}^{\circ}$ Ed 2013 McGRAW-HILL Torino Fauci, AS.; Kasper, D L.; Longo, D L.; Braunwald, E.; Hauser, SL.; Jameson, JL.; Loscalzo, J.

[31] The menopause transition and post menopausal hormone therapy. Harrison's Principles of Internal Medicine, 16th edition; Kasper, D.L.; Fauci, A.S.; Longo, D.L.; Braunwald, E.; Hauser, S.L.; Jameson, J.L., Eds.; McGrawHill: NewYork, 2005; 2210-3

[32] Hemrika, DJ.; Slaats, EH.; Kennedy, JC.; de Vries Robles-Korsen ,TJ.; Schoemaker, J. Pulsatile luteinizing hormone patterns in long term oral contraceptive users. J. Clin. Endocrinol. Metab., 1993, 77 (2), 420-6

[33] Fauci, AS.; Kasper, D L.; Longo, D L.; Braunwald, E.; Hauser, SL.; Jameson, JL.; Loscalzo, J. Disorders of the ovary and female reproductive tract. Harrison'sPrinciples of Internal Medicine, 16th edition; Kasper, D.L.; Fauci, A.S.; Longo, D.L.; Braunwald, E.; Hauser, S.L.; Jameson, J.L., Eds.; McGraw-Hill: New York, 2005; 2199-209

[34] IARC. Overall evaluations of carcinogenicity: an updating of IARC Monographs volumes 1 to 42. IARC Monogr Eval Carcinog Risks Hum Suppl. 1987, 7, 120-2

[35] National Toxicology Program. NTP 12th Report on Carcinogens. Rep. Carcinog. 2011, 12, iii-499.

[36] Sagiv, SK.; Mendola, P.; Loomis, D.; Herring, AH.; Neas, LM.; Savitz, DA.; Poole, C. A time series analysis of air pollution and preterm birth in Pennsylvania, 1997-2001. Environ. Health Perspect., 2005; 113(5), 602-6

[37] Dawson, EB.; Ritter, S.; Harris, WA.; Evans, DR.; Powell, LC. Comparison of sperm viability with seminal plasma metal levels. Biol. Trace. Elem. Res., 1998, 64 (1-3), 215-9

[38] De Rosa, M.; Zarrilli, S.; Paesano, L.; Carbone, U.; Boggia, B.; Petretta, M.; Maisto, A.; Cimmino, F.; Puca, G.; Colao, A.; Lombardi, G. Traffic pollutants affect fertility in men. Hum. Reprod., 2003, 18 (5), 1055-61

[39] Weber, RF.; de Batt, C. Male fertility. Possibly affected by occupational exposure to mercury. Ned. Tijdschr Tandheelkd. 2000, 107(12), 495-8

[40] Kolstad, HA.; Bonde, JP.; Spano, M.; Giwercman, A.; Zschiesche, W.; Kaae, D.; Larsen, SB.; Roeleveld, N. Change in semen quality and sperm chromatin structure following occupational styrene exposure. Int. Arch. Occup. Environ. Health., 1999, 72 (3), 135-41

[41] Watanabe, N. Decreased number of sperms and Sertoli cells in mature rats exposed to diesel exhaust as fetuses. Toxicol. Lett., 2005, 155 (1), 51-8

[42] Young, EA.; Midgley, AR.; Carlson, NE.; Brown, MB. Alteration in the hypothalamic-pituitary-ovarianaxis in depressed women. Arch. Gen. Psych., 2000, 57(12), 1157-62.

[43] Meller, WH.; Grambsch, PL.; Bingham, C.; Tagatz, GE. Hypothalamic pituitary gonadal axis dysregulation in depressed women. Psychoneuroendocrinology., 2001, 26 (3), 253-9

[44] Massoni, F.; Simeone, C.; Luzi, E.; Palla, C.; Ricci, S. Appropriateness prescribing and doctor's professional responsibility. Clin Ter., 2012, 163 (4), e193-9.

[45] ACGIH. American Conference of Governmental Industrial Hygienist. Documentation of the threshold limit values and biological exposure indices. 7th Ed Cincinnati. 2012; OH.

[46] Faglia, G.; Beck-Peccoz, P.; Spada, A. Malattie del sistema endocrino e del metabolismo. Malattie ipotalamo-ipofisarie. $V^{\circ}$ Ed 2013 McGRAW-HILL Torino, 44-46
[47] Duarte-Davidson, R.; Courage, C.; Rushton, L.; Levy, L. Benzene in the environment: an assessment of the potential risks to the health of the population. Occup. Environ. Med., 2001, 58 (1), 2-13

[48] Ippoliti, F.; Corbosiero, P.; Canitano, N.; Massoni, F.; Ricciardi, MR.; Ricci, L.; Archer, T.; Ricci, S. Work- related Stress, overnutrition and cognitive disability. Clin. Ter., 2017, 168 (1), e42-e47

[49] Massoni, F.; Simeone, C.; Luzi, E.; Palla, C.; Ricci, S. Appropriateness prescribing and doctor's professional responsibility. Clin. Ter., 2012, 163 (4), e193-9.

[50] Massoni, F.; Salesi, M.; Sarra, MV.; Ricci, S. Absence from work and the medical sickness certificate. Panminerva Med., 2013, 55(1), 99-105

[51] Ralli, M.; Balla, MP.; Greco, A.; Altissimi, G.; Ricci, P.; Turchetta, R.; de Virgilio, A.; de Vincentiis, M.; Ricci, S.; Cianfrone, G. Work-Related Noise Exposure in a Cohort of Patients with Chronic Tinnitus: Analysis of Demographic and Audiological Characteristics. Int. J. Environ. Res. Public. Health., 2017, 14(9)

[52] Tomei, F.; Ricci, S.; Giammichele, G.; Sacco, C.; Loreti, B.; Fidanza, L.; Ricci, P.; Scala, B.; Tomei, G.; Rosati, MV. Blood pressure in indoor and outdoor workers. Environ Toxicol Pharmacol., 2017, 55, 127-36.

[53] Spaziani, E.; Silecchia, G.; Ricci, S.; Raparelli, L.; Materia, A.; Fantini, A.; Basso, N. Minimally invasive approach for the treatment of idiopathic varicocele. Surg. Laparosc. Endosc., 1997, 7 (2), 140-3

[54] Massoni, F.; Cassese, M.; Nicoletti, M.; Ricci, S. Rupture of the right ventricular wall closed with Daflon patching and biological glue. Clin. Ter., 2012, 163 (4), e177-80.

[55] Tomei, F.; Rosati, MV.; Baccolo, TP.; Cherubini, E.; Ciarrocca, M.; Caciari, T.; Tomao, E. Ambulatory (24 hours) blood pressure monitoring in police officers. J. Occup. Health., 2001, 46 (3), 23543

[56] Tomao, E.; Baccolo, TP.; Rosati, MV.; Marcellini, L.; Tomei, F. The effects of air pollution on the lipid balance of traffic police personal. Ann. Saudi Med., 2002, 22 (5-6), 287-90.

[57] Volpino, P.; Tomei, F.; La Valle, C.; Tomao, E.; Rosati, MV.; Ciarrocca, M.; De Sio, S.; Cangemi, B.; Vigliarolo, R.; Fedele, F. Respiratory and cardiovascular function at rest and during exercise testing in a healthy working population: effects of outdoor traffic air pollution. Occup. Med., 2004, 54 (7), 475-82

[58] De Sio, S.; Rosati, MV.; Cherubini, E.; Ciarrocca, M.; Baccolo, TP.; Grimaldi, F.; Caciari, T.; Tomao, E.; Tomei, F. Occupational exposure to urban pollutants and plasma insulin. Saudi Med. J., 2005, 26 (3), 416-20

[59] Ciarrocca, M.; Tomei, G.; Fiaschetti, M.; Caciari, T.; Cetica, C.; Andreozzi, G.; Capozzella, A.; Schifano, MP.; Andre', JC.; Tomei, F.; Sancini, A. Assessment of occupational exposure to benzene, toluene and xylenes in urban and rural female workers. Chemosphere., 2012, 87 (7), 813-9

[60] Crebelli, R.; Tomei, F.; Zijno, A.; Ghittori, S.; Imbriani, M.; Gamberale, D.; Martini, A.; Carere, A. Exposure to benzene in urban workers: environmental and biological monitoring of traffic police in Rome. Occup. Environ. Med., 2001, 58 (3), 165-71.

[61] Casale, T.; Sacco, C.; Ricci, S.; Loreti, B.; Pacchiarotti, A.; $\mathrm{Cu}-$ pelli, V.; Arcangeli, G.; Mucci, N.; Antuono, V.; De Marco, F.; Tomei, G.; Tomei, F.; Rosati, MV. Workers exposed to low levels of benzene present in urban air: Assessment of peripheral blood count variations. Chemosphere., 2016,152, 392-8

[62] Bulka, C.; Nastoupil, LJ.; McClellan, W.; Ambinder, A.; Phillips, A.; Ward, K.; Bayakly, AR.; Switchenko, JM.; Waller, L.; Flowers, $\mathrm{CR}$. Residence proximity to benzene release sites is associated with increased incidence of non-Hodgkin lymphoma. Cancer., 2013, 119 (18), 3309-17

[63] Polychronakis, I.; Dounias, G.; Makropoulos, V.; Riza, E.; Linos, A. Work-related leukemia: a systematic review. J Occup. Med. Toxicol., 2013, 8(1), 14

[64] Reutman, SR.; LeMasters, GK.; Knecht, EA.; Shukla, R.; Lockey, JE.; Burroughs, GE.; Kesner, JS. Evidence of reproductive endocrine effects in women with occupational fuel and solvent exposures. Environ. Health. Perspect., 2002, 110 (8), 805-11. 